\title{
Scenes from the Battlefield: A Feminist Resists the Writing Workshop
}

I intend here to argue that the contemporary creative writing classroom, with its emphasis on the traditional workshop model of teaching, actively suppresses both feminist radical writing and avant-garde writing, and therefore is complicit in the more general tendency of academic institutions to perpetuate the racist, sexist, elitist, and heterosexist status quo.

You will note that I have chosen to separate into two categories "feminist radical writing" and "avant-garde writing." Despite the historically persistent presence of "experimentalist women writers," the category "avant-garde" still tends to connote a white male community, who, I would suggest, arrive at experimental writing from a different beginning of emphasis. As Hal Foster has said about the postmodern visual arts, there exists a postmodernism of reaction and a postmodernism of resistance. The avant-garde has tended to tend the progress of society, has tended to react to (conventional and/or modernist) forms; while feminist radical writers have tended to resist forms, to effect revision of society's root practices. True enough: differences between avant-garde and feminist radical writers tend to be nuanced, and so alliances have tended to form. But these alliances are shaky.

To explore this shaking a bit further, I turn to a recent contribution to the field of writing about avant-garde writing, Ronald Sukenick's Narralogues: Truth in Fiction. Sukenick writes, "Postmodernism in fiction may be considered, in part, a rebellion against the constraints of mimesis in favor of a return to the rhetorical tradition." Which rhetorical tradition? He recognizes that "rhetoric can be the blunt instrument of power" and that "forms of discourse embody our most profound, if veiled, political investments." Most resisting writers would agree with these observations, but shouldn't the vestments of that rhetorical tradition be undone? "Fiction is a matter of argument rather than of dramatic representation." Well, ok, fiction emerges from an author's authoritative point of view and should therefore be con- 
sidered a persuasive document, I agree-but why argument? Why that most masculinist of rhetorical battlefields, rife with proving, asserting, accusing, blaming? "We can judge the truth of fiction in the same way we can consider the persuasiveness of any argument." Is that still true when the fiction attempts to resist (in ways This Essay will not) a combative structure such as persuasion?

Indeed, the "persuasions" of masculinist argument are often ad womanem in nature. For instance, D. W. Fenza, in a "dialogue" staged in the May 1993 pages of The AWP Chronicle, intimated that a doctoral candidate named Kassie Fleisher might well be a "deranged psycho-babbler." Evidence of her possible hysteria was her "argument" in support of the view that (in Fenza's paraphrase) "meanings are indeterminate." Fleisher had been invited (oh, so collegially) by Fenza to defend the usefulness of literary theory to creative writers. Yet Fenza seemed bent on deeming Fleisher's "willful misreading" of another contributor's piece an "hallucinatory speculation," and scolded her for having misspelled "bogeyman," doubtless because he thought she was one. Fleisher is rumored to have abandoned all hope of AwP's becoming a more inclusionary community, and canceled her membership.

More subtly than Fenza's bushwhack, the "dialogues" of Sukenick's narralogues, dead-head-on as they often are about art, are pseudo-Socratic in structure-and that's a structure which requires hierarchy, an uneven distribution of power between the knowing and the quizzed. In the narralogue "Chat," Sukenick's Waldo meets up with a "jeune-fille" who wins "a point in her favor" when she says she likes Rabelais. Their (clearly competitive) conversation is narrated from Waldo's point of view, so jeune-fille is subjected to his gaze (we're not told what this "plain and pious looking" student with a "pneumatic fleshiness" thinks of Old Fart Waldo who judges people by whether they like Rabelais and are fleshy). Having accepted her presence, and her interest in his status, Waldo "took her into the woods. It was late spring...." And since we know Sukenick knows what he's doing, we know he knows what he's doing when pseudo-Socrates "takes" an American college student into the woods in late spring. It's clear from the narralogue that plain Jane (that's her name, natch) is less knowledgeable than The Big Bad Wolf, and so she has less power, sexually and intellectually: When the self-ironic narrator prompts her to 
be less "Socratic," she replies, "I'll try, but I don't even know what you mean exactly." Ultimately, Waldo has done with Little Red Riding Hood: "He left her standing there, mouth open as if to say something which, luckily, he would never have to hear." And while Sukenick happily spoofs intellectual and sexual traditions like Plato's Dialogues and that thing to which an old man's fancy turns in the woods come spring, the "suppression" (i.e., rape) of anyJane and her open mouth (i.e., what women want to say in our jejune and oral way) are cultural structures that go unresisted in "Chat." And since we know Sukenick knows what he's doing, we know that if he had intended to resist these structures, he would have done more than represent them.

Not that there's anything wrong with his choice. But while the notion of fiction as competitive serial monologue and "judgment" of "persuasiveness" does constitute reaction (within a contemporary context), some resistors seek manylogues, a root activist tongue of rebellion. And that would be rebellion with a cause. And the cause would be: saving ourselves (and other Others) from continuing suppression, of the open-mouthed, silenced variety.

Which is to say that action, and reaction, is not the same as activism. Hence the booty-shaking of the alliance.

D. G. Myers has asserted that creative writing had its origins in "conservative reform." He argues that it ultimately promised, among other radical changes, more participation for women, thus "putting an end to" women's exclusion "from the literary profession." I will not assume the same promise held for people of color, gays, and the working classes. And: Myers's trumpeting of the "end" of the exclusion of women in creative writing remains...trumpeting...not least because our institutional emphasis on affirmatively actious "inclusion" has been rightfully challenged by third wave feminism and thinkers of color. Yes, the first master's thesis accepted at Iowa in 1931 was written by a woman (Mary Roberts's Paisley Shawl). Yes, white women have been the primary benefactors of affirmative action, and women now receive the majority of master's and doctoral degrees in English.

Women also hold the vast majority of non-tenure track non-jobs in English, and are widely outnumbered among the ranks of tenured faculty. 
But alas, this is not simply about numbers, not least because affirmative action has aided the erasure of marginalized activity. In the 1980s, the problem was defined by some of us as the "Sandra Day O'Connor Syndrome"; shortly thereafter redubbed the "Clarence Thomas Syndrome"; soon to be redubbed [insert Bush Supreme Court nominee here]. To wit: institutionalizing a sexed body, or a skin-colored body, does not necessarily diversity make. Does not necessarily "inclusion" make, if we mean by inclusion an expansion of modes of thinking, reading, talking, resisting. Which is to say, hiring or promoting (thus including) a woman does not necessarily mean hiring or promoting a feminist. Not to mention a radical feminist. Affirmative reaction has altered the face of the institution while sub-alterning the thought; has served, as Gayatri Spivak has argued, to institutionalize essentialism, to enforce homogeneity of aesthetics and ideology. Gilles Deleuze and Felix Guattari propose an alternative, nomadic thought which aims to resist the hierarchical control of representational identity- to resist an identity defined by the state's intensifying of difference, rather than honoring of difference.

And we know difference is a constant in workshops. We know this because last week, she liked that poem and you didn't.

Spivak, Deleuze and Guattari, and so many others suggest that discontinuity and fragmentation (tools shared by reactionary and resistant writers), while perhaps uncomfortable to some, are perhaps uncomfortable because they are the real opponents of the hegemonic control of Who We Are and What We Stand For. I would add that when avant-garde thinking and aesthetics do occasionally find a home (a johnny's paycheck) in creative writing, that (institutionalized) aesthetic is often a reactionary one and not a resistant one; is one that privileges (say) literary sentence-play over (say) literature of social revolution. Thus, in terms of texts, the reactionary avant-garde risks being used as yet another normalizing institutional tool, yet another means of pretending "inclusion" while excluding foundational threat. The reactionary avant-garde risks becoming a force that does not guard advancement so much as a force that guards what came before-i.e., itself.

All of which to insist that Myers - while well intended, I'm sure - is ill-equipped to expose the "place" of resisting artists in the industry that is creative writing. Counting noses will not do it. 
Myers reports, again, that creative writing emerged within English studies as a matter of conservative dissent. I'd add that the industry, given its refusal to welcome the study of contemporary theory - a study that would encourage consideration of differencehas matured to codify that conservative dissidence. Where we have supported patriarchy, and instituted essentialism, we have a responsibility - especially as educators - to reform ourselves, and not just for the sake of argument. As educators, we might address the question asked by transformational pedagogues: Since education changes a student (not to mention faculty), one way or the other and whether she wants it to or not, shouldn't we structure an educational experience that changes her (us) for the better?

Once upon a time, in a land far away, a master-father castrated his daughter's long, apprentice sentences. Our tale begins in the master's dark, wood-paneled office, autumn leaves dashing against the ivy clinging to his window. He spends hours gripping red pen, pouring over the apprentice's promising young "stories." His eyes blur, his family calls (he is, of course, married)... but the daughter's "stories" would be saved. They would be trimmed, sculpted, sliced to order. She could be the new Ann Beattie, the clitorized Carver, if only he could make her so. He toils and he sacrifices, gives the apprentice hours he could have applied to his own clipped, taut, Vintage(d) work. When she objects to the bloody scars on her manuscript he strokes his beard and sighs. If only she understood his sacrifice of time, of logos. Finally, she, Vintage-awed, in search of her father's agent, relents. She slashes sentences, minimalizes, inserts his projectile plot structures, offers in jest to add his name as coauthor. And ok, yes, she fucks him once or twice, since that is what the stroking of logos can lead to (see Waldo and Jane, above). Then she leaves his tutorial. And her sentences, like the vines near his window in spring, begin to grow back- to cascade in waves like Virginia's crashing orgasms.

Another true story: What's a daughter to do when she comes to workshop and her instructor says - and I quote- "We all know you're gay already - why don't you write about something else?"

Which brings us from the question of form to the question of content. Feminist scholars of autobiography, including Sidonie Smith and Estelle Jelinek, have explored the typical differences in 
subject matter between male and female authors; I think we may safely extrapolate some tendencies in the content of poetry as well. Women, and others whose "articulations of self" are uttered from a "subhegemonic" social position, tend to utilize reportorial tones and self-deprecating humor when confessing bad news; subaltern authors often assume that their readers are part of their own marginalized group, and so often make the subjected the subject; women affect an intimacy with the reader, speaking as one would to a close friend about what one would tell a close friend. And, as Patricia Myer Spacks has observed, women's selection of subject matter often "exploits a rhetoric of uncertainty...partly as a mode of self-denial."

The exhausting contradiction between urges toward self-articulation and self-denial is of course reflected in subject matter, and content selection should be read and understood on such terms, rather than dismissed, as has historically been the case, as "domestic fiction." As Joanna Russ vows in How to Suppress Women's Writing, "The Double Standard of Content is perhaps the fundamental weapon in the armory.... The trick...is to label one set of experiences as more valuable and important than the other." Or, as Virginia Woolf wrote in A Room of One's Own, "A scene in a battlefield is more important than a scene in a shop."

Disclaimer: I'm not here to argue for a realist representation of "subject matter." But whatever your conventions of choice-and as that workshop instructor revealed recently - the little shop of lesbian sexuality is less valued than the battlefield of male heterosexual fantasy. This sort of authority-ridden classroom, rampant in creative writing, is a deceitful classroom. It allows the uncontested acting-out of binary oppositions that in practice are neither useful nor healthy. The teacher/student binary hides the fact that teachers often learn from their students, that students often do not learn from their teachers, and that an artistic community of colleagues may be formed between both. The right/wrong grammar binary, with the works/doesn't-work aesthetic binary, hides the fact that language can and should contain multitudes of usages and receptions (fragmentation being the primary opponent of... [see above]). The conventional/experimental binary results in the dismissal of the alternative language practices and subject matters 
developed by women, gays, people of color, and the working classes-especially those many who do not rely on hegemonic, "realist" expressions of their disenfranchisement. The insistence upon sole authorship, an historical development closely related to the commodification of art - and the resultant competition for survival that plagues many artistic communities - still plays out in workshops today, hiding an activist world of anti-corporate co-laboratories such as the one that produced This Essay.

Radical (resistant) writing undercuts these authoritative structures at their roots. So does radical teaching and learning. Thus we conclude: Non-radical teaching - teaching that does not address these root institutional deceptions, and does not engage la frontera (see Gloria Anzaldúa) amidst different aesthetics and ideologieswill but of course inherently stifle radical art intending to illuminate that difference, especially the resistant writing of women, gays, people of color, and the working classes.

How to reclaim, without mystification, an activist role for creative writing? [Insert here title of forthcoming book on radical methods for teaching creative writing, because "how to" questions seem to be the only questions my collaborator and I receive when presenting our ideas - despite our insistence throughout that the whys and whos of teaching should prefigure the whats.] The means of reclamation will vary from practitioner to practitioner, but one central classroom feature must be undone before any reclamation is possible: the fundamental master/apprentice, father/daughter, het/gay, have/not imbalances in the teacher-student relationship. In its place, language theory, heterology, critique of institutional roles, and exploration of the reader-writer's reception of his/her/Other's writing.

In the future, we may perhaps avow with good old-fashioned collegiate verve that the creative writing classroom, home of resistant makers of enacting-art, exerts an action which critiques authority, which action, unsurprisingly, preserves the advancement of writing that challenges the root and fundamental humour necessary to the vitality of society as it might be, transforming the student writer, the teacher-student, and the writing community in ways that tend the many progresses of those many logos in society. 